\title{
Journal of Soils and Sediments \\ Soil properties and plant community relationship in a saltmarsh of the Grado and Marano lagoon (Northern Italy) \\ --Manuscript Draft--
}

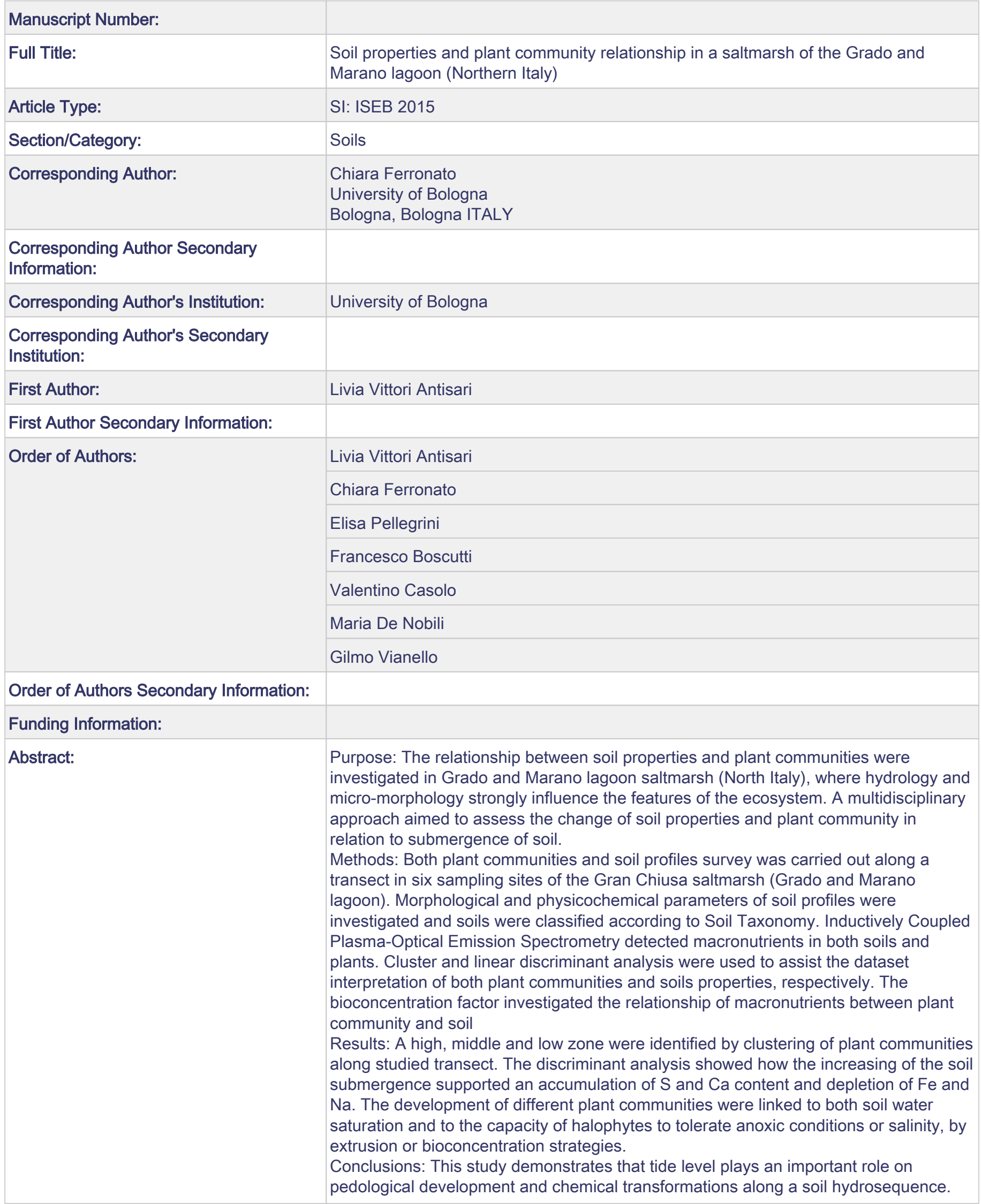




\begin{tabular}{|l|l|}
\hline & $\begin{array}{l}\text { The vegetation micromosaic can therefore represent a useful index of the hydrological } \\
\text { and nutritional status of the underlying soils and be used to predict changes in coastal } \\
\text { ecosystems. }\end{array}$ \\
\hline Suggested Reviewers: & $\begin{array}{l}\text { José Álvarez Rogel } \\
\text { Universidad Politecnica de Cartagena } \\
\text { jose.alvarez@upct.es } \\
\text { He is expert on wetland plant zonation }\end{array}$ \\
\hline $\begin{array}{l}\text { Carmelo Dazzi } \\
\text { University of Palermo } \\
\text { carmelo.dazzi@unipa.it } \\
\text { he is and expert soil scientist }\end{array}$ & $\begin{array}{l}\text { Xose Luis Otero } \\
\text { Universidade de Santiago de Compostela } \\
\text { xl.otero@usc.es } \\
\text { he is expert of soil chemistry in wetlands }\end{array}$ \\
\hline Opposed Reviewers: & \begin{tabular}{l} 
\\
\hline
\end{tabular} \\
\hline
\end{tabular}


Soil properties and plant community relationship in a saltmarsh of the Grado and

\section{Marano lagoon (Northern Italy)}

Authors: Livia Vittori Antisari ${ }^{1}$, Chiara Ferronato ${ }^{1}$, Elisa Pellegrini ${ }^{2}$, Francesco Boscutti ${ }^{2}$, Valentino Casolo ${ }^{2}$, Maria de Nobili ${ }^{2}$, Gilmo Vianello ${ }^{1}$

${ }^{1}$ Dipartimento di Scienze Agrarie, Alma Mater Studiorum Università di Bologna, viale Fanin 40, 40127, Bologna, IT

${ }^{2}$ Dipartimento di Scienze AgroAlimentari, Ambientali e Animali, Università di Udine, via delle Scienze, 206, 33100, Udine, IT.

Corresponding author: Chiara Ferronato, Dipartimento di Scienze Agrarie, Alma Mater Studiorum Università di Bologna, viale Fanin 40, 40127, Bologna, IT, e-mail: chiara.ferronato2@unibo.it; Phone +390512096230

Keywords: saltmarsh, hydromorphic soil, subaqueous soil, plant community, transition, submergence 


\section{Abstract}

Purpose: The relationship between soil properties and plant communities were investigated in Grado and Marano lagoon saltmarsh (North Italy), where hydrology and micro-morphology strongly influence the features of the ecosystem. A multidisciplinary approach aimed to assess the change of soil properties and plant community in relation to submergence of soil.

Methods: Both plant communities and soil profiles survey was carried out along a transect in six sampling sites of the Gran Chiusa saltmarsh (Grado and Marano lagoon). Morphological and physicochemical parameters of soil profiles were investigated and soils were classified according to Soil Taxonomy. Inductively Coupled Plasma-Optical Emission Spectrometry detected macronutrients in both soils and plants. Cluster and linear discriminant analysis were used to assist the dataset interpretation of both plant communities and soils properties, respectively. The bioconcentration factor investigated the relationship of macronutrients between plant community and soil

Results: A high, middle and low zone were identified by clustering of plant communities along studied transect. The discriminant analysis showed how the increasing of the soil submergence supported an accumulation of $\mathrm{S}$ and $\mathrm{Ca}$ content and depletion of Fe and $\mathrm{Na}$. The development of different plant communities were linked to both soil water saturation and to the capacity of halophytes to tolerate anoxic conditions or salinity, by extrusion or bioconcentration strategies.

Conclusions: This study demonstrates that tide level plays an important role on pedological development and chemical transformations along a soil hydrosequence. The vegetation micromosaic can therefore represent a useful index of the hydrological and nutritional status of the underlying soils and be used to predict changes in coastal ecosystems. 


\section{Introduction}

Coastal ecosystems are complex and fragile systems which high ecological value is worldwide recognized (Barbier et al., 2011; Reddy and DeLaume, 2008). They harbor high biodiversity levels, providing important habitats for a large number of both migratory and resident birds and support important ecosystem services such as, regulation of the bio-geochemical cycles of nutrients and trace elements (de Groot et al., 2012; Gedan et al., 2010; Homann and Grigal, 1996; Ponnamperuma, 1972).

Moreover, about $10 \%$ of the global population live in coastal areas (McGranahan et al., 2007; UNEP, 2006), and local economies are often based on fishery, farming and tourism (Beaumont et al., 2007; Worm et al., 2006). The rising of the sea level (IPCC AR4 SYR, 2007) and the overexploitation of coastal areas have led to the increase of erosion processes and to a considerable reduction and degradation of coastal habitats (Halpern et al., 2008; Lotze et al., 2006), in particular those of saltmarshes and mudflats. The degradation of these ecosystems, leads to serious problems linked to land management (Fontolan et al., 2012), protection and maintenance of the inner shore line and for wildlife conservation (Beaumont et al., 2007; Ferrarin et al., 2010).

The consolidation of saltmarshes and mudflats can be considerably improved by halophytes, which foster soil pedogenesis retaining sediments with roots, affecting the redox conditions in the rhizosphere, and providing an important source of organic carbon for microbial communities and soil development (Laanbroek, 2010; Nyman et al., 1993; Reddy and DeLaume, 2008). In this context, the halophytic vegetation appears to be characterized by a micromosaic distribution that can be linked to the properties of the soils underneath (Álvarez Rogel et al., 2001; Van Wijnen and Bakker, 1999). In these environments, soil hydrology has a profound effect on plant colonization, and the inability to define a general evolutionary trend, testify the complexity of the system (Silvestri et al., 2005). In this study, soil properties and plant communities changes were investigated along an increasing gradient of flooding 
and anoxic stress conditions, considering also salinity and nutrients availability (Álvarez

Rogel et al., 2001; Van Wijnen and Bakker, 1999). According to the Demas' theory on soil subaqueous soils (Demas and Rabenhorst, 1999), Ferronato et al. (2016) considered the formation and development of soil continuum from subaqueous to hydromorphic system. In this context, the bathymetry, as a proxy of waterlogging, can be considered as one of the main soil forming factor (Demas and Rabenhorst, 2001), which influences several abiotic and biotic factors linked to the hydrodynamic of saltmarshes, such as the variability of soil properties and the occurrence of different pedogenetic processes along a soil hydrosequence. The number of soil profiles that need to be excavated is a key issue in soil surveys. Decisions are based on the well-known connections between topography and soil substrate on one side and ecological communities, on the other (Wysocki et al., 2012). However, the assessment of variations in a saltmarsh environment, where subtle variations in height (microrelief) have profound effect on soil hydrology, is much more challenging.

In agreement with this view, a soils hydrosequence and the related vegetation cover were studied in the saltmarsh of the Gran Chiusa Isles (Grado and Marano Lagoon, northern Italy). In this study, a cross section of the island, traced from the inner part to the submerged zone, was surveyed. Both plant community distribution and soil survey were carried out with the aim to: i) describe the change of soil properties according to the frequency and length of the soil submergence, and ii) define the relationship among soil position in the hydromorphic sequence, its properties, and plant cover values.

\section{Materials and methods}

\section{The study area}

The Grado and Marano lagoon (SPA/SAC Nature 2000: IT3320037) is one of the largest Italian lagoons. It extends for $160 \mathrm{~km}^{2}$ between the Tagliamento and the Isonzo river mouths in the Northern Adriatic Sea. The lagoon is delimited by seven natural barriers, which are 
separated by lagoon inlets (Brambati et al., 1998). The climate of the area is classified as "temperate/mesothermal" (Peel and Bloschl, 2011), characterized by mean annual temperature of $15.1{ }^{\circ} \mathrm{C}$ and by $969 \mathrm{~mm} \mathrm{yr}^{-1}$ of precipitation (OSMER, 2016). Water temperatures range between $5-7^{\circ} \mathrm{C}$ in winter and $28-30^{\circ} \mathrm{C}$ in summer and the tide oscillation range between 65 and $105 \mathrm{~cm}$ (Ferrarin et al., 2010).

The sampling survey was performed in July 2014 on the main saltmarsh area of the Gran Chiusa Isles, a great complex of saltmarshes of about $0.87 \mathrm{~km}^{2}$, located in the central part of the lagoon, in the Buso basin. According to the LIDAR models, this area reaches elevations of about $70 \mathrm{~cm}$ on the a.m.s.l. on its abrupt canal margin, and presents a gradual depression in the inner part of the saltmarsh. However, the increase of the sea level (ICCP, 2007) and periodical field observations made difficult to establish to establish the exact $0 \mathrm{~m}$ a.m.s.l. and the absolute altitudes of the tidal area. Several channels branch out the saltmarsh in all directions, some of them, with straight and regular features, testify the former use of this saltmarsh as a fishing valley.

\section{Sampling method and field analysis}

A $70 \mathrm{~m}$ long transect was traced from the inner part to the edge of the salt marsh and sampling sites (form GC-a to GC-f) were selected according to six different zones of sitespecific topography, hydroperiod (hours per day ${ }^{-1}$, ISPRA, 2013) and vegetation cover (Figure 1). Notice that the quotes reported in Figure 1 have been corrected according to field observation (Fontolan et al., 2013).

In each site, the vegetation surveys were conducted in three plots of $4 \mathrm{~m}^{2}(2 \times 2 \mathrm{~m})$ within each area. Plant communities were described referring to the most abundant species (percentage of cover), following the nomenclature reported in Biondi et al. (2014). Nomenclature of plant taxa followed the latest Italian check list of vascular plants (Conti et al., 2005). In each site, 
samples of the most representative and abundant species were collected in plastic cases, and stored at $4^{\circ} \mathrm{C}$ until analysis.

In each site, a soil profile was excavated or collected using a Beeker vibracore sampler (Eijkelkamp, NL) equipped with a polyethylene tube with a diameter of $6 \mathrm{~cm}$. Soil profiles were described in field according to the guideline of McVey et al. (2012) and of Schoeneberger et al. (2012), including the $\mathrm{H}_{2} \mathrm{O}_{2}$, and colour change and soil incubation test for the detection of sulphidic materials (Fanning et al., 2002; McVey et al., 2012). Each soil profile was further classified according to the USDA Soil Taxonomy (Soil Survey Staff, 2014). In order to avoid oxygen infiltration, samples were immediately sealed with a tight stopper and stored at $4^{\circ} \mathrm{C}$, until laboratory analysis.

\section{Soil and plant samples analysis}

For the physicochemical characterization, samples were air-dried and sieved at $2 \mathrm{~mm}$ and soil particle size distribution was determined by pipette method (Gee and Bauder, 1986). The $\mathrm{pH}$ (pHmeter, Crison, Germany) and the electrical conductivity (EC; conductimeter Orion, Germany) of each sample were measured on 1:2.5 (w:v) soil:distilled water suspension. The content of total carbonates $\left(\mathrm{CaCO}_{3}\right)$ were quantified by volumetric method (Loeppert and Suarez, 1996), while the total organic carbon (OC) and total nitrogen (TN) were measured by Dumas combustion with a CHN elemental analyser (EA 1110 Thermo Fisher, USA) after dissolution of carbonates with $2 \mathrm{M} \mathrm{HCl}$.

For the detection of total macro elements content, samples were finely grounded and digest with aqua regia solution in a microwave oven (Milestone, 1200). Inductive Coupled PlasmaOptic Emission Spectroscopy (ICP-OES, Ametek, Germany) processed the mineralized soil solution.

Plant samples were washed in deionized water in order to remove soluble salts and sediment deposited on the tissues and then oven-dried at $60^{\circ} \mathrm{C}$ for $48 \mathrm{~h}$. The content of total macro 
elements was determined by Inductive Coupled Plasma- Optic Emission Spectroscopy (ICPOES, Ametek, Germany) after digestion of the finely grounded dry biomass in microwave oven with a solution of $\mathrm{H}_{2} \mathrm{O}_{2}$ and $\mathrm{HNO}_{3}(2: 6 \mathrm{v}: \mathrm{v})$ according to Vittori Antisari et al. (2011).

All analyses were performed in duplicate; reference materials (BCR-320R and BCR 062) and reagent blanks were used to check the accuracy of the measurements and the agreement was typically $10 \%$.

\section{Data analysis}

Differences between the chemical composition of soil samples were evaluated with one way analysis of variance (ANOVA) and post-hoc tests (Tukey test, $\mathrm{p}<0.05$ ), whereas a Student's $\mathrm{t}$ test was applied to check for plant samples composition difference. Normality of data was verified using the Shapiro's test for normality $(\mathrm{p}>0.05)$, while the homogeneity of variances was tested using the Bartlett's test $(\mathrm{p}>0.05)$.

A multivariate approach was used to assist the interpretation of the dataset. A hierarchical cluster analysis, using the Bray-Curtis dissimilarity as distance matrix and the complete link method for the clustering, was performed to describe the sites plant communities. A discriminant analysis (DA) with forward stepwise method was performed to identify the key variables that discriminate the different soil profiles according to their vegetation cover (Wilk's lambda $<0.0009 ; \mathrm{p}<0.001$ ). The standardized canonical discriminant coefficients were evaluated to rank the importance of each variables while the structure matrix was used to assign meaningful labels to the linear discriminant functions (LD). The soil-plant relationships were investigated through the calculation of the bioconcentration factor (BCF) of macronutrients in each plant community. The BCF was calculated as the ratio between the total element concentration in plant $\left(\mathrm{mg} \mathrm{kg}^{-1}\right)$ and in the soil $\left(\mathrm{g} \mathrm{kg}^{-1}\right)$ according to $\mathrm{Li}$ and Zheng (2011). 


\section{Results}

\section{Vegetation pattern along the hydrosequence}

The characterization of plant communities along the hydrosequence was performed by a cluster analysis. The analysis of the dendrogram (Figure 2) showed the presence of two cut levels (i.e. 0.98 and 0.70). The first indicated three main clusters (clusters 1, 2, 3), corresponding to the high (cluster 2), middle (cluster 3) and subaqueous (cluster 1) part of the saltmarsh. The latter was characterized by green algae cover (cluster 1), whereas in cluster 2 and 3, further five different subclusters were identified (namely, A, B, C, D, E).

Within cluster 2, subcluster B referred to the vegetation class of Juncetea maritimi, representing the mediterranean perennial salty and brackish grasslands; subcluster $\mathrm{C}$ encompassed both GC-b and GC-c zones, referred to Sarcocornietea fruticosae class, that includes pioneer, perennial, hyperhalophilous, succulent, woody and semi-woody plant communities. In subcluster B, the most abundant plant, occurring in all plots, was Juncus maritimus (80\% on average), followed by Limonium narbonense (27\%) Sarcocornia fruticosa (23\%) and Atriplex portulacoides (12\%), while in the latter (subcluster C), the most aboundant species were L. narbonense (65\%), S. fruticosa (13\%) and Spartina maritima $(13 \%)$.

Similarly, also cluster 3 can be interpreted as a combination of two different vegetation patterns found in the middle zone (Figure 2, subcluster D and E). The subcluster D showed a mean cover of $95 \%$ of Sp. maritima and was ascribed to the Spartinetea glabrae class, which include all pioneer vegetation of perennial formations that grow on muddy brackish soils inundated for long period. The subcluster E showed the prevalence of Salicornia patula (72\%) and referred to the class Thero-Suaedetea splendentis, encompassing all pioneer communities of annual species of the genus Salicornia, in temporarily inundated saltmarsh sites and in saltpans. 


\section{Classification and properties of soil hydrosequence}

The morphological description of soil profiles (Table 1S) highlighted that all soils were little developed with a silty or silty loam texture, generally showing an $\mathrm{A} / \mathrm{AC} / \mathrm{C}$ pedosequence, except for the presence of $\mathrm{BC}$ horizons in the GC-a profile, and of a $\mathrm{L}$ (limnic) horizon in the GC-f pedon. (Table 1S).

Figure 3 summarizes some of the morphological features of soil profiles. The pedons in the high zone (GC-a, GC-b and GC-c, cluster 2) presented many roots sheaths in the topsoil and some shell fragments in the deeper $\mathrm{C}$ horizon. Conversely, the pedons located in the submerged zone (GC-d, GC-e and GC-f, cluster 3 and 1, respectively) presented common shell fragments in the A horizons and organic films and concentrations in the deeper one. Sulphidic materials were detected in the topsoil of the highest pedons and in the subsoil of submerged profiles, and increased from the inner part of the saltmarsh to its edge (Figure 3). Despite the accumulation of these materials in the investigated pedons, sulfic horizons were not detected because of the lack of pH failure during aerobic incubation (McVey et al, 2012). All the soil profiles collected in GC-a, GC-b, GC-c and GC-d zones showed evidence of aquic conditions, due to periodic saturation and reduction processes, while GC-e and GC-f pedons had a positive water potential at the soil surface for more than 21 hours per day (ISPRA, 2013; Soil Survey Staff, 2014) and were thus ranked into the Wassent suborder. Soil profiles in the high part of the saltmarsh (GC-a, GC-b and GC-c, Cluster 2) were classified as Typic Endoaquent, while in the middle part (cluster 3), the classification of GC-d and GC-e fell into the Typic Hydraquent and Typic Hydrowassent great groups respectively. In the lowest part of the saltmarsh (Cluster 1), GC-f pedon was classified as Typic Fluviwassent.

Table 1 reports the main physicochemical characteristics of each genetic horizons and the significant differences among the mean values of the investigated pedons.

Among the different profiles, the subaqueous GC-f soil presented significant higher $\mathrm{pH}$ values and lower EC values than GC-c pedon ( $p=0.018$ and 0.006 respectively). Irregular $\mathrm{CaCO}_{3}$ 
distribution along the soil profile was mainly due to intercalation of shell fragments in several layers (Table 1). The OC and TN content decreased along the soil profiles, with exception of the subaqueous Fluviwassent profile (GC-f), where organic-enriched layers were recorded along the soil profile. Moreover, the post-hoc test highlighted a significant higher content of OC in GC-c (Typic Endoaquent) than the pedons located in the low part of the salt marsh $(p<0.05)$. Significant higher EC value and Na content in GC-c pedon than those in GC-f was also detected $(p=0.011)$. Among the investigated profiles, the macronutrients content (e.g. K, $\mathrm{Fe} \mathrm{Al}$ ) in the subaqueous soils was significant lower than that in GC-a pedon. Conversely, $\mathrm{Ca}$ and $\mathrm{S}$ amount was significantly higher (Table1).

A discriminant analysis (DA) was performed on three a priori groups of soils, chosen according to the results of the cluster analysis (cut level=0.98), using the soil physicochemical parameters above described (Figure 4) as independent variables. The canonical structure matrix (Table 2) was used to discuss the most relevant variables which compose the discriminant functions (greater than 0.3).

The first Linear Discriminant function (LD1) separated the subaqueous Fluviwassent (GC-f) soil properties from those of the pedons in the middle and high zone of the saltmarsh (clusters 2 and 3, respectively). Notably, cluster 3 included both hydromorphic (GC-d, Hydraquent) and subaqueous soils (GC-e, Hydrowassent), while cluster 2 was only composed by hydromorphic Endoaquent soils. The canonical structure matrix (Table2) showed that among the relevant variables of $\mathrm{LD} 1, \mathrm{EC}, \mathrm{CEC}, \mathrm{Na}, \mathrm{Fe}$ and $\mathrm{Al}$ increased from the subaqueous to hydromorphic system, while S and Ca content followed the opposite trend.

The variables involved in LD2 separated the soils of cluster 3 in the middle zone of the saltmarsh (covered by Spartinetea glabrae and Thero-Suaedetea splendentis classes), from those of cluster 2 in the highest zone (covered by Juncetea maritimi and Sarcocornietea fruticosae). The driving variables were $\mathrm{pH}, \mathrm{S}$ and $\mathrm{Ca}$ amount, which were higher in cluster 3 soils (Typic Hydraquent and Typic Hydrovassent); conversely, EC, Na, P, OC content and 
$\mathrm{C} / \mathrm{S}$ ratio decreased from the Endoaquent pedons (cluster 2) to Hydraquent and Hydrowassent ones (cluster 3$)$.

\section{Soil-vegetation relationship}

Table 3 presents the main macronutrients concentration measured in the plants corresponding to the two groups obtained from the cluster analysis (cut level=0.98, cluster 2, 3). Cluster 3 (GC-d/e sites located in the middle zone of the transect), mostly covered by Spartina maritima and Salicornia patula, had a significantly higher content of $\mathrm{Ca}(\mathrm{p}=0.050), \mathrm{K}$ $(\mathrm{p}=0.011)$ and $\mathrm{Fe}(\mathrm{p}=0.008)$ than that determined in the plant tissues of the cluster $2(\mathrm{GC}-\mathrm{a} / \mathrm{b} / \mathrm{c}$ sites, located in the highest zone). Notice that these last two plant communities types were characterized by dominance of Juncus maritimus (GC-a) the first and of Limonium narbonense and Sarcocornia fruticosa (GC-b/c) the second. In addition, the content of the other macronutrients in plant tissues $(\mathrm{Mg}, \mathrm{Na}, \mathrm{P}, \mathrm{S})$ were slightly higher in cluster 3 than that in cluster 2, but no significant difference was detected.

In order to assess the different capacities of plant communities to absorb nutrients from soil, the bioconcentration factor $(\mathrm{BCF})$ of macronutrients, with respect to soil, was calculated for all the plant samples of cluster 2 and 3. As shown in Figure 5, some statistical significant differences were found between the two groups.

$\mathrm{K}(p=0.004)$ and $\mathrm{Fe}(p=0.016) \mathrm{BCF}$ were significantly higher in the plant communities adapted to survive in more frequently submerged areas (cluster 3, GC-d/e sites) than those located in the high zone of the saltmarsh. On the contrary, plants of these communities (Spartinetea glabrae and Thero-Suaedetea splendentis classes) showed a significant low BCF for $\mathrm{S}(\mathrm{p}=0.150)$ in comparison to specimens referring to Juncetea maritimi and Sarcocornietea fruticosae classes (cluster 2).

The other macronutrients did not show a significant differences; however, the $\mathrm{BCF}$ of $\mathrm{P}, \mathrm{Mg}$ and $\mathrm{Na}$ appeared higher in cluster 3, while BCF of Ca showed an opposite trend. 


\section{Discussion}

The vegetation survey, in the Gran Chiusa saltmarsh, identified three main vegetation groups and a high variability of features within the pedological sequence, which highlighted the system transition from the subaqueous to the hydromorphic environment.

The macro areas separated by cluster analysis (high, middle and low zone), reflected the distribution of some important physicochemical parameters of soils groups, as highlighted by the discriminant analysis.

The highest soil profiles of the hydrosequence (GC-a, b, c) showed a relatively weaker signs of reduction than the other soils, due to a shorter period of submerge, and they were soluble salt-enriched. Accumulation of $\mathrm{Na}$ and soluble salts noted in superficial horizons of these soils, are probably linked to continuous flooding/evaporation processes and to other oxidation processes (Ferronato et al., 2016; Salama et al., 1999). These phenomena were more evident in the GC-c pedon. Furthermore the $\mathrm{C}: \mathrm{S}$ ratio, which is an indicator of anoxic pedogenesis (Ferronato et al., 2016; Ivanov et al., 1989), being larger in anoxic environment, increases in these soils with respect to the profiles in the lower part of the saltmarsh .

Indeed, the low $\mathrm{C}: \mathrm{S}$ ratio of the submerged soils and soil horizons, and detection of strong sulphidic odour during the profile description, indicate that in the permanently saturated zones of the saltmarsh, the soils are characterized by accumulation of reduced $\mathrm{S}$ compounds, OC enrichment and anoxic pedogenesis (Demas and Rabenhorst, 1999; Ferronato et al., 2016). The sulfidization is a typical pedogenetic process of marsh soils (Fanning and Fanning, 1989; Fanning et al., 2002) where the chemical and microbiological reduction of $\mathrm{SO}_{4}{ }^{2-}$ into $\mathrm{HS}^{-}$, lead to the formation of iron-sulphide compounds, that define the sulphidic horizons (Demas and Rabenhorst, 1999; Fanning and Fanning, 1989). In the soils transect of the Gran Chiusa saltmarsh, the formation of these horizons was not possible, because although layers with accumulation of sulphides were observed where soil was permanently saturated (e.g. in the C 
horizons of $\mathrm{GC}-\mathrm{a} / \mathrm{b} / \mathrm{c}$ highest profiles, and in the A horizons of GC-d/e/f lowest pedons), the expected consequent acidification was not detected. For this reason, according to the Soil Taxonomy (Soil Survey Staff, 2014), these horizons were not considered as diagnostic sulfic horizons. Because the sulphides accumulation reflects important pedogenic pathways in the saltmarsh pedons, the lack of acidification during the aerobic $\mathrm{pH}$ detection must be ascribed to the buffering action due to high carbonate and $\mathrm{Ca}$ content in investigated soil (Vittori Antisari et al., 2016).

In the middle position of the investigated hydrosequence, Typic Hydraquent (GC-d) and Typic Hydrowassent (GC-e) coexist, reflecting a typical transition zone in micro-morphologically depressed areas within the saltmarshes.

According to the physicochemical data and to the DA, the physicochemical features of these soils are similar to those of Endoaquent mainly due to the increase of EC and other macronutrients, but also to those of Fluviwassent for their moderate content of $\mathrm{S}$ and $\mathrm{Ca}$, due to water saturation. Spartina maritima and Salicornia patula, for 95 and $72 \%$, respectively, cover these transition pedons, suggesting that these species are particularly adapted to growth under severe conditions, such as low oxygen availability, soil salinity and water saturation (Zhang et al., 2006; Zuo et al., 2012). The species adaptation in saltmarshes depends on a number of edaphic factors that act at both macro and micro-morphological scale, such as the bathymetry, the oxygen availability, the redox status of the soil, the life cycle of the species, and their capacity to adapt and tolerate severe environmental conditions (Génin et al., 1998; Pedersen et al., 2013). In this paper, we suggest that the nutrients content of the plant tissues and the bioconcentration factor $(\mathrm{BCF})$ could be useful tool to depict the interaction between soil-vegetation cover systems.

The higher content of $\mathrm{Fe}, \mathrm{K}$ and $\mathrm{Mg}$ in the plants living in low saltmarshes communities (Spartinetea glabrae and Thero-Suaedetea splendentis classes), with respect to other species established in highest saltmarsh areas can be ascribed to anaerobic conditions, which 
determines the reduction and mobility of several nutrients e.g. Fe, K, Ca (Julie and Siobhan, 2001).

At micro-edaphic scale, the results also confirm that the plants uptake depends on both soil properties (e.g. soil salinity and water saturation) and by specie-specific factors linked to the plant metabolism and adaptation (Silvestri et al., 2005). For example, the highest Na content in plant tissues was recorded in the class Thero-Suedetea splendentis, where the salt resistant S. patula was the most abundant species (Ushakova et al. 2005, Sajna et al. 2013).

Conversely, the plant communities located in the high zone need to face a high $\mathrm{Na}$ concentration and they adopt several mechanisms to tolerate $\mathrm{Na}$, such as the development of epidermal glands able to secrete salt from leaves (e.g. in Limonium genus) or the increase of leaf or stem succulence (e.g. Sarcocornia genus). Furthermore, the capacity of Sp. maritima and $S$. patula to colonize transition areas and anoxic soils, where sulphides and other reductive species are found, can be ascribed to their capacity to avoid passive $S^{2-}$ uptake (Havill et al., 1985), as confirmed by the low BCF of S.

\section{Conclusion}

This paper points out the existence of a significant relationship in saltmarshes between soil types and plant communities along soil hydrosequences. The vegetation micromosaic can therefore represent a useful index of the hydrological and nutritional status of the underlying soils. Indeed, the soil classification scheme and the vegetation clustering were able to reflect the micro-morphology of the area and the evolution of different soil-forming processes linked to the lack of oxygen in soil, such as sulfidization processes and nutrients mobilization. The distribution of the vegetation pattern along the hydrosequence largely depend on the capacity of plants to adopt resistance strategies to colonize the different environmental and soil conditions. 
This study demonstrates that tide level plays an important role on pedological development

\section{Acknowledgments}

Thanks are due to the Regional Agency for the Environmental Protection (ARPA) of Friuli Venezia Giulia for the technical support and the regional Protezione Civile for providing LiDAR data and orthophotos of sites.

\section{References}

Álvarez Rogel, J., Ortiz Silla, R., Alcaraz Ariza, F., 2001. Edaphic characterization and soil ionic composition influencing plant zonation in a semiarid Mediterranean salt marsh. Geoderma 99, 81-98. doi:10.1016/S0016-7061(00)00067-7

Barbier, E.B., Hacker, S.D., Kennedy, C., Koch, E.W., Stier, A.C., Silliman, B.R., 2011. The value of estuarine and coastal ecosystem services. Ecol. Monogr. 81, 169-193. doi:10.1890/10-1510.1

Beaumont, N.J., Austen, M.C., Atkins, J.P., Burdon, D., Degraer, S., Dentinho, T.P., Derous, S., Holm, P., Horton, T., van Ierland, E., Marboe, A.H., Starkey, D.J., Townsend, M., Zarzycki, T., 2007. Identification, definition and quantification of goods and services provided by marine biodiversity: implications for the ecosystem approach. Mar. Pollut. Bull. 54, 253-65. doi:10.1016/j.marpolbul.2006.12.003

Biondi, E., BLASI, C., Allegrezza, M., Anzellotti, I., Azzella, M.M., Carli, E., Casavecchia, S., Copiz, R., Del Vico, E., Facioni, L., Galdenzi, D., Gasparri, R., Lasen, C., Pesaresi, S., Poldini, L., Sburlino, G., Taffetani, F., Vagge, I., Zitti, S., Zivkovic, L., 2014. Plant communities of Italy: The Vegetation Prodrome. Plant Biosyst. - An Int. J. Deal. with all Asp. Plant Biol. 148, 728-814. doi:10.1080/11263504.2014.948527

Brambati, A., De Muro, S., Marocco, R., Selivanov, A., 1998. Barrier island evolution in relation to the sea-level changes: the example of the Grado Lagoon (northern Adriatic Sea, Italy). Boll. di Geofis. Teor. ed Appl. 39, 145-161. 
Conti, F., Abbate, G., Alessandrini, A., Blasi, C., 2005. An annotated check-list of the italian vascular flora. Palombi ed. Roma.

de Groot, R., Brander, L., van der Ploeg, S., Costanza, R., Bernard, F., Braat, L., Christie, M., Crossman, N., Ghermandi, A., Hein, L., Hussain, S., Kumar, P., McVittie, A., Portela, R., Rodriguez, L.C., ten Brink, P., van Beukering, P., 2012. Global estimates of the value of ecosystems and their services in monetary units. Ecosyst. Serv. 1, 50-61. doi:10.1016/j.ecoser.2012.07.005

Demas, G., Rabenhorst, M.C., 1999. Subaqueous Soils: Pedogenesis in a Submersed Environment. Soil Sci. Soc. Am. J. 63, 1250-1257.

Demas, G.P., Rabenhorst, M.C., 2001. Factors of subaqueous soil formation: a system of quantitative pedology for submersed environments. Geoderma 102, 189-204. doi:10.1016/S0016-7061(00)00111-7

Fanning, D.S., Fanning, M.C.B., 1989. Soil: Morphology, genesis, and classification. John Wiley \& Sons, New York.

Fanning, D.S., Rabenhorst, M.C., Burch, S.N., Islam, K.R., Tangren, S.A., 2002. Sulfides and sulfates, in: Soil Mineralogy with Environmental Applications. SSSA, Madison, WI.

Ferrarin, C., Umgiesser, G., Bajo, M., Bellafiore, D., De Pascalis, F., Ghezzo, M., Mattassi, G., Scroccaro, I., 2010. Hydraulic zonation of the lagoons of Marano and Grado, Italy. A modelling approach. Estuar. Coast. Shelf Sci. 87, 561-572. doi:10.1016/j.ecss.2010.02.012

Ferronato, C., Falsone, G., Natale, M., Zannoni, D., Buscaroli, A., Vianello, G., Vittori, L., 2016. Chemical and pedological features of subaqueous and hydromorphic soils along a hydrosequence within a coastal system ( San Vitale Park, Northern Italy ). Geoderma 265, 141-151. doi:10.1016/j.geoderma.2015.11.018

Fontolan, G., Covelli, S., Bezzi, A., Emili, A., Martinucci, D., Pellegrini, E., Pillon, S., Popesso, C., 2013. Studio delle aree barenicole della laguna di Grado e Marano.

Fontolan, G., Pillon, S., Bezzi, A., Villalta, R., Lipizer, M., Triches, A., D’Aietti, A., 2012. Human impact and the historical transformation of saltmarshes in the Marano and Grado Lagoon, northern Adriatic Sea. Estuar. Coast. Shelf Sci. 113, 41-56. doi:10.1016/j.ecss.2012.02.007

Gedan, K.B., Kirwan, M.L., Wolanski, E., Barbier, E.B., Silliman, B.R., 2010. The present and future role of coastal wetland vegetation in protecting shorelines: answering recent challenges to the paradigm. Clim. Change 106, 7-29. doi:10.1007/s10584-010-0003-7

Gee, G.W., Bauder, J.W., 1986. Methods of Soil Analysis: Part 1-Physical and Mineralogical Methods, Methods of Soil Analysis: Part 1-Physical and Mineralogical Methods, SSSA Book Series. Soil Science Society of America, American Society of Agronomy. doi:10.2136/sssabookser5.1.2ed.c15 
Génin, J.-M.R., Bourrié, G., Trolard, F., Abdelmoula, M., Jaffrezic, A., Refait, P., Maitre, V., Humbert, B., Herbillon, A., 1998. Thermodynamic Equilibria in Aqueous Suspensions of Synthetic and Natural Fe(II)-Fe(III) Green Rusts: Occurrences of the Mineral in Hydromorphic Soils. Environ. Sci. Technol. 32, 1058-1068. doi:10.1021/es970547m

Halpern, B.S., Walbridge, S., Selkoe, K.A., Kappel, C. V, Micheli, F., D’Agrosa, C., Bruno, J.F., Casey, K.S., Ebert, C., Fox, H.E., Fujita, R., Heinemann, D., Lenihan, H.S., Madin, E.M.P., Perry, M.T., Selig, E.R., Spalding, M., Steneck, R., Watson, R., 2008. A global map of human impact on marine ecosystems. Science 319, 948-52. doi:10.1126/science. 1149345

Havill, D.C., Ingold, A., Pearson, J., 1985. Sulphide tolerance in coastal halophytes, in: Beeftink, W.G., Rozema, J., Huiskes, A.H.L. (Eds.), Ecology of Coastal Vegetation. Springler, Dordrecht, pp. 279-285. doi:10.1007/978-94-009-5524-0

Homann, P.S., Grigal, D.F., 1996. Below-ground organic carbon and decomposition potential in a field-forest glacial-outwash landscape. Biol. Fertil. Soils 23, 207-214. doi:10.1007/BF00336065

IPCC AR4 SYR, 2007. Climate Change 2007: Synthesis Report, Contribution of Working Groups I, II and III to the Fourth Assessment Report of the Intergovernmental Panel on Climate Change, IPCC. Pachauri R.K; and Reisinger A., ed.

ISPRA, 2013. Servizio Laguna di Venezia - Rete meteo-mareografica [WWW Document]. URL http://www.venezia.isprambiente.it/rete-meteo-mareografica (accessed 1.20.16).

Ivanov, M.V., Yu, A., Reeburgh, M.S., Skyring, G.W., 1989. Interaction of sulphur and carbon cycles in marine sediments, in: Evolution of Global Biogeochemical Sulphur Cycle. John Wiley \& Son Ltd.

Julie, K.C., Siobhan, F.M., 2001. Wetland Plants: Biology and Ecology. CRC Press.

Laanbroek, H.J., 2010. Methane emission from natural wetlands: interplay between emergent macrophytes and soil microbial processes. A mini-review. Ann. Bot. 105, 141-53. doi:10.1093/aob/mcp201

Li, S.-X., Zheng, F.-Y., 2011. Effect of macronutrient enrichment on the size distribution, sorption, and bioconcentration factor of iron by coastal phytoplanktonic diatoms. Mar. Environ. Res. 72, 89-95. doi:10.1016/j.marenvres.2011.06.001

Loeppert, R.H., Suarez, D.L., 1996. Carbonate and Gypsun. USDA-ARS/UNL Fac.

Lotze, H.K., Lenihan, H.S., Bourque, B.J., Bradbury, R.H., Cooke, R.G., Kay, M.C., Kidwell, S.M., Kirby, M.X., Peterson, C.H., Jackson, J.B.C., 2006. Depletion, degradation, and recovery potential of estuaries and coastal seas. Science 312, 1806-9. doi:10.1126/science.1128035

McGranahan, G., Balk, D., Anderson, B., 2007. The rising tide: assessing the risks of climate change and human settlements in low elevation coastal zones. Environ. Urban. 19, $17-$ 


\section{7. doi:10.1177/0956247807076960}

McVey, S., Schoeneberger, P.J., Turenne, J., Payne, M., Wysocki, D.A., 2012. Subaqueous soils (SAS) description, in: Field Book for Describing and Sampling Soils. National Soil Survey Center Natural Resources Conservation Service U.S. Department of Agriculture.

Nyman, J.., DeLaune, R.D., Roberts, H.H., Patrick Jr, W.H., 1993. Relationship between vegetation and soil formation in a rapidly submerging coastal marsh. Mar. Ecol. Prog. Ser. 96, 269-279.

OSMER, 2016. Osservatorio meteorologico regionale del FVG [WWW Document]. URL http://www.meteo.fvg.it/clima.php?ln=\&m=0 (accessed 2.18.16).

Pedersen, O., Colmer, T.D., Sand-Jensen, K., 2013. Underwater photosynthesis of submerged plants - recent advances and methods. Front. Plant Sci. 4, 140. doi:10.3389/fpls.2013.00140

Peel, M.C., Bloschl, G., 2011. Hydrological modelling in a changing world. Prog. Phys. Geogr. 35, 249-261. doi:10.1177/0309133311402550

Ponnamperuma, F.., 1972. The chemistry of submerged soils. Adv. Agron. 24, $29-95$.

Reddy, R.K., DeLaume, D., 2008. Biochemistry of wetlands. Science and applications. Taylor $\&$ Francis.

Salama, R.B., Otto, C.J., Fitzpatrick, R.W., 1999. Contributions of groundwater conditions to soil and water salinization. Hydrogeol. J. 7, 46-64. doi:10.1007/s100400050179

Schoeneberger, P., Wysocki, D.A., Benham, E.C.J., 2012. Field book for describing and sampling soils, Version 3.0. Natural Resources Conservation Service, National Soil Survey Center, Lincoln, NE.

Silvestri, S., Defina, A., Marani, M., 2005. Tidal regime, salinity and salt marsh plant zonation. Estuar. Coast. Shelf Sci. 62, 119-130. doi:10.1016/j.ecss.2004.08.010

Soil Survey Staff, 2014. Keys to Soil Taxonomy, 12th ed. United States Department of Agriculture, Natural Resources Conservation Service.

UNEP, 2006. Marine and coastal ecosystems and human well-being: a synthesis report based on the findings of the Millennium Ecosystem Assessment.

Van Wijnen, H.J., Bakker, J.P., 1999. Nitrogen and phosphorus limitation in a coastal barrier salt marsh: the implications for vegetation succession. J. Ecol. 87, 265-272. doi:10.1046/j.1365-2745.1999.00349.x

Vittori Antisari, L., Carbone, S., Ferronato, C., Simoni, A., Vianello, G., 2011. Characterization of heavy metals atmospheric deposition for urban environmental quality in the Bologna city (Italy). EQA - Int. J. Environ. Qual. doi:10.6092/issn.2281$4485 / 3834$

Vittori Antisari, L., De Nobili, M., Ferronato, C., Natale, M., Pellegrini, E., Vianello, G., 
2016. Hydromorphic to subaqueous soils transitions in the central Grado lagoon (Northern Adriatic Sea, Italy). Estuar. Coast. Shelf Sci. in press.

Worm, B., Barbier, E.B., Beaumont, N., Duffy, J.E., Folke, C., Halpern, B.S., Jackson, J.B.C., Lotze, H.K., Micheli, F., Palumbi, S.R., Sala, E., Selkoe, K.A., Stachowicz, J.J., Watson, R., 2006. Impacts of biodiversity loss on ocean ecosystem services. Science 314, 78790. doi:10.1126/science. 1132294

Wysocki, D.A., Schoeneberger, P.., Hirmas, D., La Garry, H.., 2012. Geomorphology of soil landscapes, in: P.M. Huang et Al. (ed.) Handbook of Soil Science: Properties and Processes, 2nd Ed. CRC Press, Taylor and Francis Group, LLC, Boca Raton, FL. ISBN: 978-1-4398-0305-9.

Zhang, D., Yang, M., Li, J., Chen, X., 2006. Vegetative Dispersal Ability of Spartina alterniflora in Eastern End of Chongming Island(Chinese). J. East China Norm. Univ. 2006, 130-135.

Zuo, P., Zhao, S., Liu, C., Wang, C., Liang, Y., 2012. Distribution of Spartina spp. along China's coast. Ecol. Eng. 40, 160-166. doi:10.1016/j.ecoleng.2011.12.014 
Table 1. Physicochemical characterization of soil profiles. Pairwise post-hoc Turkey test results are reported with different letters on the statistically different groups.

\begin{tabular}{|c|c|c|c|c|c|c|c|c|c|c|c|c|c|c|c|c|c|}
\hline Profile & Maste & th & $\mathbf{p H}^{*}$ & $\begin{array}{c}\text { EC* } \\
\mathrm{mS} \mathrm{cm} \text { cm }^{-1}\end{array}$ & $\mathrm{CaCO}_{3}$ & OC* & TN & $\mathbf{K}^{*}$ & $\mathbf{P}$ & $\begin{array}{l}\mathrm{S}^{*} \\
\mathrm{~g} \mathrm{~kg}\end{array}$ & $\mathbf{A l} *$ & $\mathbf{F e}^{*}$ & Mn & Mg & Ca* & $\mathrm{Na}^{*}$ & $\mathrm{C} / \mathrm{S}^{*}$ \\
\hline \multirow{8}{*}{ GC-a } & $\mathbf{A}$ & $0-12 / 13$ & 7.6 & 22.1 & 107.2 & 43.8 & 4.9 & 11.7 & 0.50 & 2.3 & 35.9 & 20.2 & 0.5 & 23.6 & 30.4 & 20.5 & 19 \\
\hline & A2 & $12 / 13-21 / 22$ & 7.8 & 16.8 & 131.3 & 25.4 & 2.2 & 11.4 & 0.40 & 1.3 & 35.3 & 21.4 & 0.7 & 25.9 & 33.3 & 15.3 & 20 \\
\hline & BC & $21 / 22-36$ & 7.9 & 16.2 & 150.3 & 21.8 & 2.1 & 12.2 & 0.33 & 1.6 & 37.8 & 17.8 & 0.2 & 24.6 & 31.4 & 14.3 & 14 \\
\hline & $\mathrm{C1}$ & $36-45 / 47$ & 7.9 & 14.1 & 178.6 & 13.1 & 1.1 & 11.8 & 0.30 & 1.3 & 37.0 & 18.1 & 0.1 & 24.9 & 32.3 & 11.7 & 10 \\
\hline & $\mathrm{C} 2$ & $45 / 47-54$ & 7.9 & 15.1 & 142.9 & nd & nd & 11.8 & 0.23 & 6.3 & 35.7 & 17.1 & 0.3 & 24.4 & 50.0 & 12.3 & nd \\
\hline & & Mean & 7.8 & 16.8 & 142.1 & 26.0 & 2.6 & 11.8 & 0.4 & 2.5 & 36.3 & 18.9 & 0.4 & 24.7 & 35.5 & 14.8 & 15.8 \\
\hline & & $S D$ & 0.1 & 3.1 & 26.2 & 12.9 & 1.6 & 0.3 & 0.1 & 2.1 & 1.0 & 1.8 & 0.2 & 0.8 & 8.2 & 3.5 & 4.6 \\
\hline & Pairwi & se post-hoc & $a b$ & $a b$ & $n s$ & $a b$ & $n s$ & $b$ & $n s$ & $a$ & $b$ & $b$ & $n s$ & $n s$ & $a$ & $a b$ & $b$ \\
\hline \multirow{7}{*}{ GC-b } & A1 & $0-18 / 20$ & 7.5 & 23.9 & 154.7 & 41.5 & 3.9 & 12.5 & 0.41 & 2.3 & 37.4 & 18.9 & 0.3 & 22.6 & 28.5 & 20.9 & 18 \\
\hline & $\mathbf{A C}$ & $18 / 20-24 / 30$ & 7.9 & 14.2 & 110.5 & 19.2 & 1.8 & 10.5 & 0.24 & 9.9 & 31.0 & 17.4 & 0.2 & 26.2 & 54.5 & 11.1 & 2 \\
\hline & C1se & $24 / 30-49 / 50$ & 8.2 & 14.3 & 44.2 & 16.4 & 1.5 & 9.7 & 0.23 & 10.2 & 27.9 & 17.3 & 0.4 & 24.1 & 57.1 & 11.4 & 2 \\
\hline & C2se & $49 / 50-60$ & 8.3 & 22.6 & 147.4 & 16.3 & 1.6 & 10.6 & 0.26 & 10.1 & 31.5 & 18.5 & 0.5 & 24.5 & 54.8 & 12.2 & 2 \\
\hline & & Mean & 8.0 & 18.8 & 114.2 & 23.3 & 2.2 & 10.8 & 0.3 & 8.1 & 32.0 & 18.0 & 0.4 & 24.4 & 48.8 & 13.9 & 5.8 \\
\hline & & $S D$ & 0.4 & 5.2 & 50.5 & 12.2 & 1.1 & 1.2 & 0.1 & 3.9 & 3.9 & 0.8 & 0.2 & 1.5 & 13.5 & 4.7 & 8.3 \\
\hline & Pairwi & se post-hoc & $a b$ & $a b$ & $n s$ & $a b$ & $n s$ & $a b$ & $n s$ & $a$ & $a b$ & $a b$ & $n s$ & $n s$ & $a b$ & $a b$ & $a b$ \\
\hline \multirow{9}{*}{ GC-c } & $\overline{\mathbf{A}}$ & $0-8 / 10$ & 6.9 & 40.2 & 19.3 & 94.0 & 8.6 & 11.3 & 0.45 & 4.2 & 29.4 & 16.1 & 0.2 & 15.3 & 15.7 & 37.4 & 22 \\
\hline & A2g & $8 / 10-15 / 16$ & 5.2 & 39.3 & 119.1 & 80.8 & 6.5 & 12.8 & 0.38 & 6.2 & 36.0 & 16.0 & 0.1 & 13.5 & 10.5 & 38.8 & 13 \\
\hline & AC1se & $15 / 16-22 / 23$ & 7.6 & 19.2 & 218.8 & 28.6 & 2.5 & 10.9 & 0.24 & 13.9 & 31.2 & 19.5 & 0.2 & 24.2 & 45.0 & 18.2 & 2 \\
\hline & AC2se & $22 / 23-41 / 42$ & 8.1 & 16.4 & 229.5 & 26.6 & 1.5 & 10.3 & 0.21 & 7.6 & 29.8 & 16.1 & 0.3 & 24.2 & 50.2 & 12.7 & 3 \\
\hline & C1g & $41 / 42-58 / 59$ & 8.0 & 15.3 & 269.6 & 34.9 & 1.3 & 9.3 & 0.20 & 9.6 & 26.2 & 15.6 & 0.4 & 24.3 & 65.3 & 11.1 & 4 \\
\hline & $\mathrm{C} 2 \mathrm{~g}$ & $58 / 59-76$ & 8.2 & 11.9 & 197.0 & 33.0 & 0.6 & 7.3 & 0.16 & 7.0 & 18.8 & 11.1 & 0.3 & 28.8 & 83.2 & 7.4 & 5 \\
\hline & & Mean & 7.3 & 23.7 & 175.6 & 49.6 & 3.5 & 10.3 & 0.3 & 8.1 & 28.6 & 15.7 & 0.3 & 21.7 & 45.0 & 20.9 & 8.2 \\
\hline & & $S D$ & 1.2 & 12.6 & 91.3 & 29.7 & 3.3 & 1.9 & 0.1 & 3.3 & 5.7 & 2.7 & 0.1 & 6.0 & 28.1 & 13.8 & 8.0 \\
\hline & Pairwi & se post-hoc & $a$ & $b$ & $n s$ & $b$ & $n s$ & $a b$ & $n s$ & $a b$ & $a b$ & $a b$ & $n s$ & $n s$ & $a b$ & $b$ & $a b$ \\
\hline \multirow{8}{*}{ GC-d } & Ag & $0-11$ & 7.9 & 15.9 & 223.3 & 23.3 & 1.9 & 10.6 & 0.24 & 15.9 & 31.5 & 22.8 & 0.2 & 24.0 & 45.9 & 12.8 & 1 \\
\hline & $\mathrm{ACg}$ & $11-24$ & 8.0 & 15.6 & 173.4 & 18.9 & 1.8 & 11.5 & 0.27 & 4.5 & 35.7 & 19.5 & 0.1 & 22.3 & 29.7 & 13.2 & 4 \\
\hline & ACse & $24-32 / 33$ & 8.1 & 12.7 & 44.7 & 16.0 & 1.4 & 11.1 & 0.22 & 6.7 & 32.6 & 17.4 & 0.2 & 25.8 & 56.9 & 10.2 & 2 \\
\hline & C1g & $32 / 33-60 / 63$ & 8.1 & 12.0 & 35.7 & 13.1 & 1.1 & 9.1 & 0.18 & 8.5 & 24.5 & 14.3 & 0.3 & 27.3 & 74.8 & 8.1 & 2 \\
\hline & $\mathrm{C} 2 \mathrm{~g}$ & 60/63-68 & 8.2 & 12.6 & 55.8 & nd & nd & 9.5 & 0.19 & 10.4 & 26.4 & 16.1 & 0.3 & 26.3 & 67.6 & 9.4 & nd \\
\hline & & Mean & 8.1 & 13.8 & 106.6 & 17.8 & 1.6 & 10.3 & 0.2 & 9.2 & 30.1 & 18.0 & 0.3 & 25.2 & 55.0 & 10.7 & 2.4 \\
\hline & & $S D$ & 0.1 & 1.8 & 85.9 & 4.3 & 0.4 & 1.0 & 0.0 & 4.3 & 4.6 & 3.3 & 0.1 & 2.0 & 17.9 & 2.2 & 1.3 \\
\hline & Pairwi & se post-hoc & $a b$ & $a b$ & $n s$ & $a$ & $n s$ & $a b$ & $n s$ & $a b$ & $a b$ & $a b$ & $n s$ & $n s$ & $a b$ & $a b$ & $a b$ \\
\hline \multirow{9}{*}{ GC-e } & Ag & $0-4$ & 8.0 & 18.7 & 58.1 & 39.4 & 5.4 & 11.4 & 0.34 & 9.2 & 33.6 & 17.9 & 0.2 & 19.5 & 48.1 & 15.8 & 4 \\
\hline & A2g & $4-16 / 17$ & 8.0 & 20.0 & 154.7 & 32.8 & 3.4 & 11.6 & 0.28 & 11.5 & 33.4 & 18.2 & 0.3 & 20.9 & 57.6 & 16.3 & 3 \\
\hline & A2se & $16 / 17-23$ & 8.1 & 13.0 & 154.7 & 19.1 & 2.1 & 10.6 & 0.23 & 11.0 & 31.3 & 18.4 & 0.3 & 25.1 & 55.4 & 11.4 & 2 \\
\hline & ACse & $23-39 / 40$ & 8.1 & 14.5 & 31.3 & 16.8 & 1.6 & 12.7 & 0.27 & 5.0 & 40.5 & 20.3 & 0.2 & 24.7 & 33.7 & 12.8 & 3 \\
\hline & C1g & $39 / 40-49 / 50$ & 8.1 & 12.9 & 88.4 & 13.6 & 1.2 & 10.0 & 0.20 & 7.6 & 28.2 & 15.9 & 0.3 & 26.8 & 63.7 & 9.8 & 2 \\
\hline & $\mathrm{C} 2 \mathrm{~g}$ & $49 / 50-60$ & 8.3 & 12.1 & 75.2 & 13.9 & 1.3 & 10.1 & 0.19 & 10.2 & 28.0 & 16.0 & 0.3 & 27.6 & 68.0 & 8.8 & 1 \\
\hline & & Mean & 8.1 & 15.2 & 93.7 & 22.6 & 2.5 & 11.1 & 0.3 & 9.1 & 32.5 & 17.8 & 0.2 & 24.1 & 54.4 & 12.5 & 2.6 \\
\hline & & $S D$ & 0.1 & 3.3 & 51.0 & 10.9 & 1.6 & 1.0 & 0.1 & 2.4 & 4.6 & 1.7 & 0.1 & 3.2 & 12.3 & 3.1 & 1.1 \\
\hline & Pairwi & se post-hoc & $a b$ & $a b$ & ns & $a$ & $n s$ & $a b$ & $n s$ & $a b$ & $a b$ & $a b$ & $n s$ & $n s$ & $a b$ & $a b$ & $a b$ \\
\hline \multirow{10}{*}{ GC-f } & Lse & $0-4$ & 8.4 & 11.8 & 189.6 & 19.3 & 2.0 & 9.9 & 0.28 & 13.5 & 29.2 & 16.8 & 0.3 & 24.1 & 61.7 & 9.5 & 1 \\
\hline & Ase & $4-16 / 18$ & 8.2 & 11.0 & 221.1 & 15.8 & 1.4 & 9.9 & 0.24 & 15.2 & 28.5 & 15.8 & 0.3 & 26.4 & 62.1 & 8.0 & 1 \\
\hline & AC1g & $16 / 18-30$ & 8.1 & 10.8 & 204.1 & 24.3 & 1.4 & 10.4 & 0.23 & 18.1 & 29.9 & 16.3 & 0.3 & 26.3 & 63.3 & 7.9 & 1 \\
\hline & AC2g & $30-40$ & 8.2 & 10.4 & 200.9 & 21.4 & 1.1 & 9.3 & 0.22 & 17.1 & 26.4 & 15.8 & 0.4 & 26.3 & 65.7 & 7.6 & 1 \\
\hline & $\mathrm{C} 2 \mathrm{~g}$ & $40-63$ & 8.4 & 10.1 & 57.5 & 23.6 & 1.0 & 7.6 & 0.21 & 13.7 & 21.1 & 13.3 & 0.4 & 28.2 & 72.0 & 7.0 & 2 \\
\hline & 2AC1g & $63-82 / 84$ & 8.5 & 9.5 & 128.8 & 21.5 & 1.0 & 8.3 & 0.21 & 13.1 & 22.6 & 12.9 & 0.3 & 27.6 & 72.9 & 6.5 & 2 \\
\hline & $2 \mathrm{AC} 2 \mathrm{~g}$ & $82 / 84-91$ & 8.5 & 9.2 & 176.9 & 23.3 & 1.0 & 8.9 & 0.22 & 12.8 & 24.6 & 13.5 & 0.3 & 27.3 & 72.2 & 6.8 & 2 \\
\hline & & Mean & 8.3 & 10.4 & 168.4 & 21.3 & 1.3 & 9.2 & 0.2 & 14.8 & 26.0 & 14.9 & 0.3 & 26.6 & 67.1 & 7.6 & 1.5 \\
\hline & & $S D$ & 0.1 & 0.9 & 57.0 & 2.9 & 0.4 & 1.0 & 0.0 & 2.1 & 3.4 & 1.6 & 0.0 & 1.3 & 5.1 & 1.0 & 0.3 \\
\hline & Pairwi & se post-hoc & $b$ & $a$ & $n s$ & $a$ & $n s$ & $a$ & $n s$ & $b$ & $a$ & $a$ & $n s$ & $n s$ & $b$ & $a$ & $a$ \\
\hline
\end{tabular}

$*=\mathbf{p}<0,05 ; \mathbf{n s}=$ non significant 
Table 2. Canonical structure matrix of LD1 and LD2 showing the correlation between the values of the explanatory variables and those of the discriminant functions. Important variables were greater than 0.30 .

\begin{tabular}{ccc}
\hline & LD 1 & LD 2 \\
\hline $\mathbf{p H}$ & -0.3 & 0.4 \\
$\mathbf{C E}$ & 0.4 & -0.4 \\
$\mathbf{C a C O} \mathbf{O}_{3}$ & -0.3 & -0.3 \\
$\mathbf{O C}$ & 0.1 & -0.4 \\
$\mathbf{T N}$ & 0.3 & -0.3 \\
$\mathbf{C S C}$ & 0.4 & -0.2 \\
$\mathbf{K}$ & 0.5 & -0.1 \\
$\mathbf{P}$ & 0.3 & -0.4 \\
$\mathbf{S}$ & -0.6 & 0.4 \\
$\mathbf{C / S}$ & 0.3 & -0.6 \\
$\mathbf{C} / \mathbf{N}$ & -0.2 & -0.2 \\
$\mathbf{A l}$ & 0.5 & -0.1 \\
$\mathbf{F e}$ & 0.5 & 0.1 \\
$\mathbf{M n}$ & -0.2 & -0.3 \\
$\mathbf{M g}$ & -0.3 & 0.2 \\
$\mathbf{C a}$ & -0.4 & 0.4 \\
$\mathbf{N a}$ & 0.4 & -0.4 \\
\hline
\end{tabular}

Table 3. Mean macronutrient concentration found in the different plant communities. Minimim ( $\min$ ), maximum (max) values and standard deviation (SD) is also reported. Data are expressed as $\mathbf{~ k g}^{-1}$, with exception of $P\left(\mathrm{mg} \mathrm{kg}^{-1}\right)$.

\begin{tabular}{|c|c|c|c|}
\hline & & $\begin{array}{c}\text { Cluster } 2 \\
(\text { GC-a/b/c) }\end{array}$ & $\begin{array}{l}\text { Cluster } 3 \\
\text { (GC-d/e) }\end{array}$ \\
\hline \multirow{4}{*}{$\mathrm{Ca}^{*}$} & Mean & 2.8 & 5.4 \\
\hline & SD & 1.3 & 2.3 \\
\hline & Min & 1.0 & 3.1 \\
\hline & Max & 3.9 & 8.1 \\
\hline \multirow{4}{*}{$\mathrm{K}^{*}$} & Mean & 5.4 & 6.0 \\
\hline & SD & 0.3 & 0.3 \\
\hline & Min & 5.0 & 5.7 \\
\hline & Max & 5.8 & 6.2 \\
\hline \multirow{4}{*}{$\mathrm{Mg}$} & Mean & 4.6 & 6.5 \\
\hline & SD & 3.5 & 2.0 \\
\hline & Min & 0.9 & 3.6 \\
\hline & Max & 10.4 & 8.1 \\
\hline \multirow{4}{*}{$\mathrm{Na}$} & Mean & 41.6 & 88.7 \\
\hline & SD & 38.3 & 57.0 \\
\hline & Min & 3.8 & 44.4 \\
\hline & Max & 105.2 & 167.8 \\
\hline \multirow{4}{*}{$\mathrm{Fe}^{*}$} & Mean & 0.3 & 2.9 \\
\hline & SD & 0.1 & 0.9 \\
\hline & Min & 0.1 & 1.6 \\
\hline & Max & 0.4 & 3.4 \\
\hline \multirow{4}{*}{ P } & Mean & 0.6 & 0.8 \\
\hline & SD & 0.3 & 0.5 \\
\hline & Min & 0.3 & 0.4 \\
\hline & Max & 1.1 & 1.4 \\
\hline \multirow{4}{*}{ S } & Mean & 3.6 & 4.0 \\
\hline & SD & 2.6 & 1.4 \\
\hline & Min & 0.6 & 2.4 \\
\hline & Max & 6.7 & 5.3 \\
\hline
\end{tabular}


Figure 1. (a) Grado and Marano Lagoon and location of the studied transect. (b) Position of the sampling points; coordinates (WGS84/ EPSG:3857) are: GC-a - 5737165.6N 1481450.3E; GC-b 5737252.0N 1481455.3E; GC-c - 5737184.2N 1481462.3E; GC-d - 5737189.6N 1481443.3E; GCe - 5737204.0N 1481447.6E; GC-f -5737249.6N 1481475.0E. (c) Elevation profile of the study transect.

Figure 2. Hierarchical clustering based on vegetation surveys (Bray-Curtis, complete link method). Tree main clusters (cut level $=0.98$, clusters $1,2,3$ ) represent the main saltmarsh areas based on height; a further separation (cut level $=0.70$, subclusters A, B, C, D, E) regards vegetation classes characterization.

Figure 3. Scheme of the morphological description of the soil profiles, displaying the intensity of sulphidic material and biological concentration (codes according to McVey et al, 2012).

Figure 4. Canonical score plot of Discriminat Analysis (DA). Wilks' Lambda: $0.0009 \mathrm{p}<0.001$.

Figure 5. Boxplots representing macronutrients bioconcentration factors (BCF) in the two main clusters $(*=\mathrm{p}<0.05)$. BCF was calculated as the ratio between nutrient concentration in plant samples and in the soil $\left(\mathrm{mg} \mathrm{kg}^{-1}\right)$. 

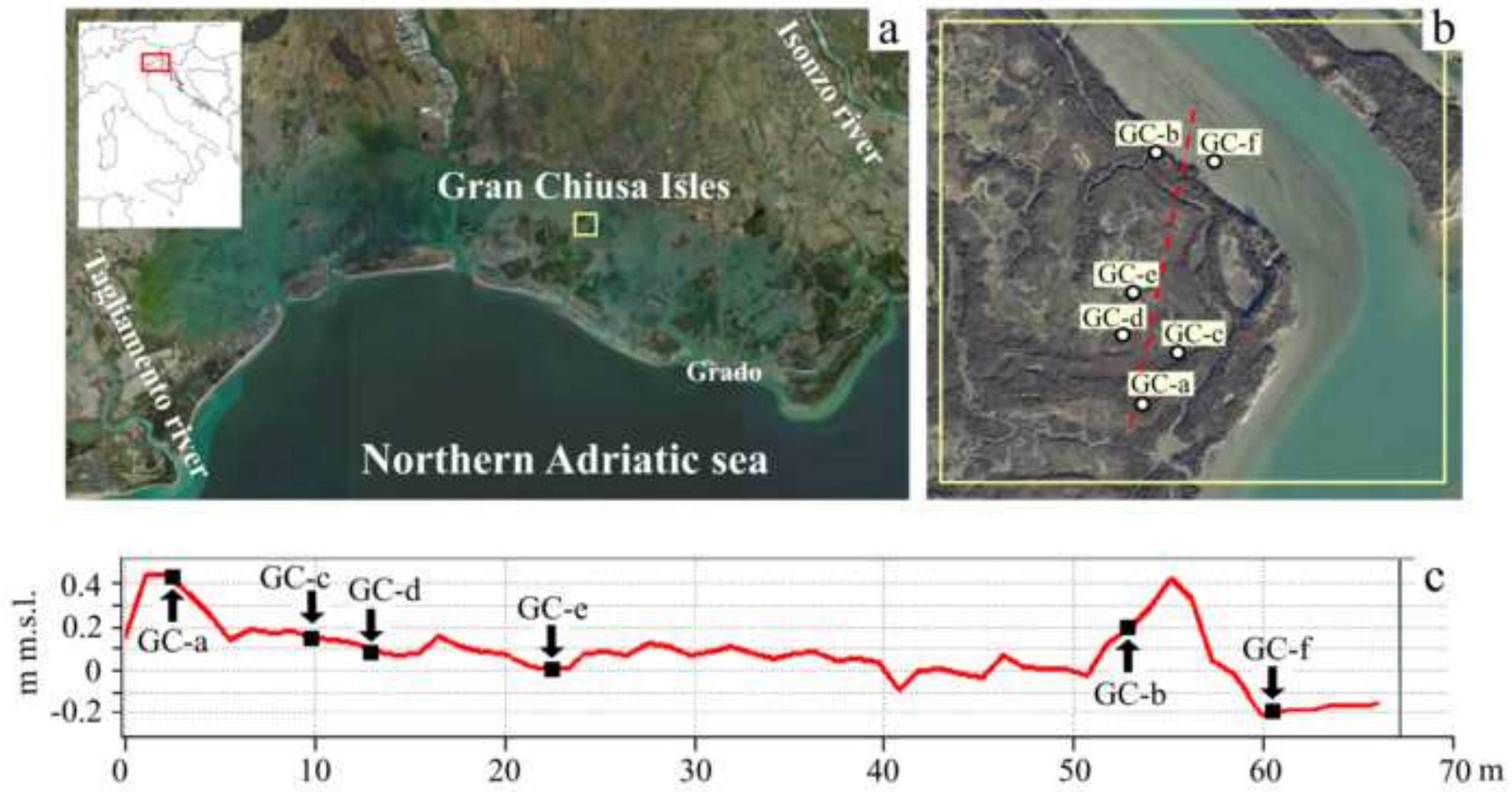


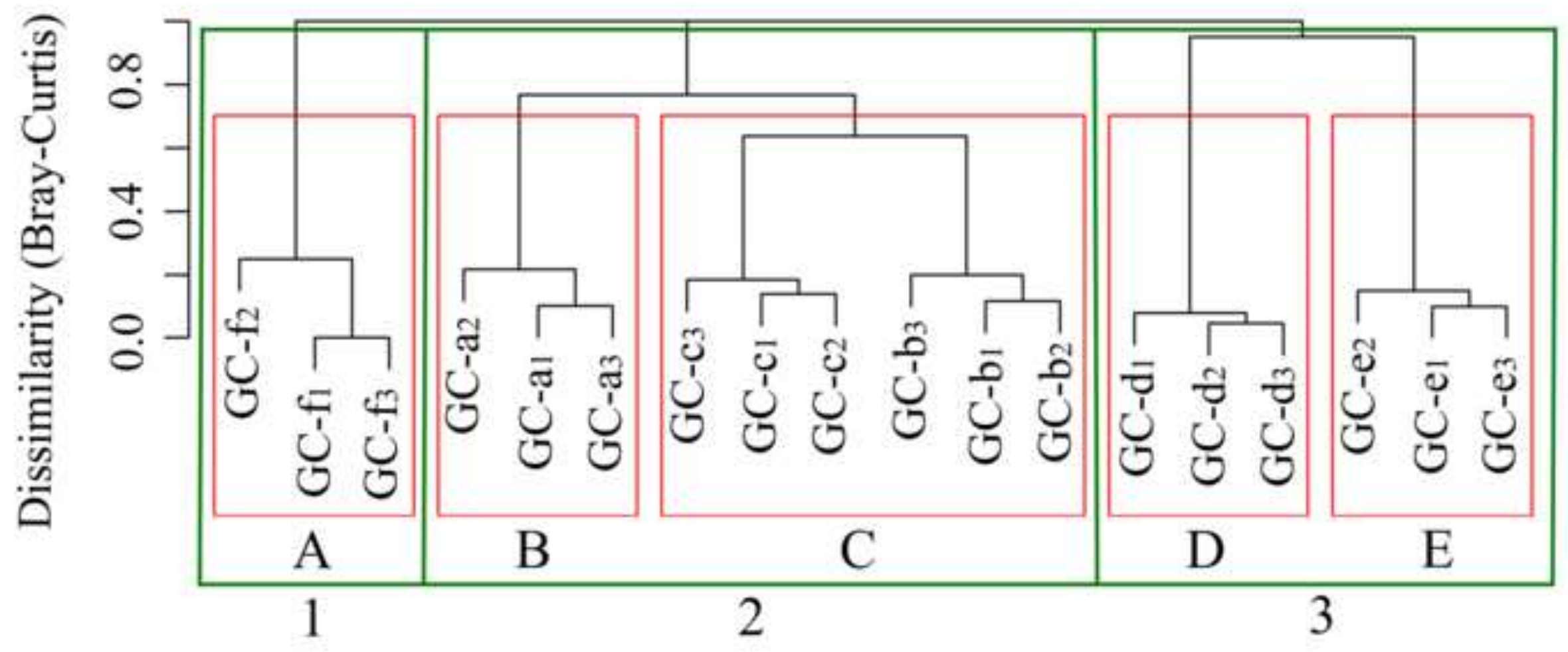




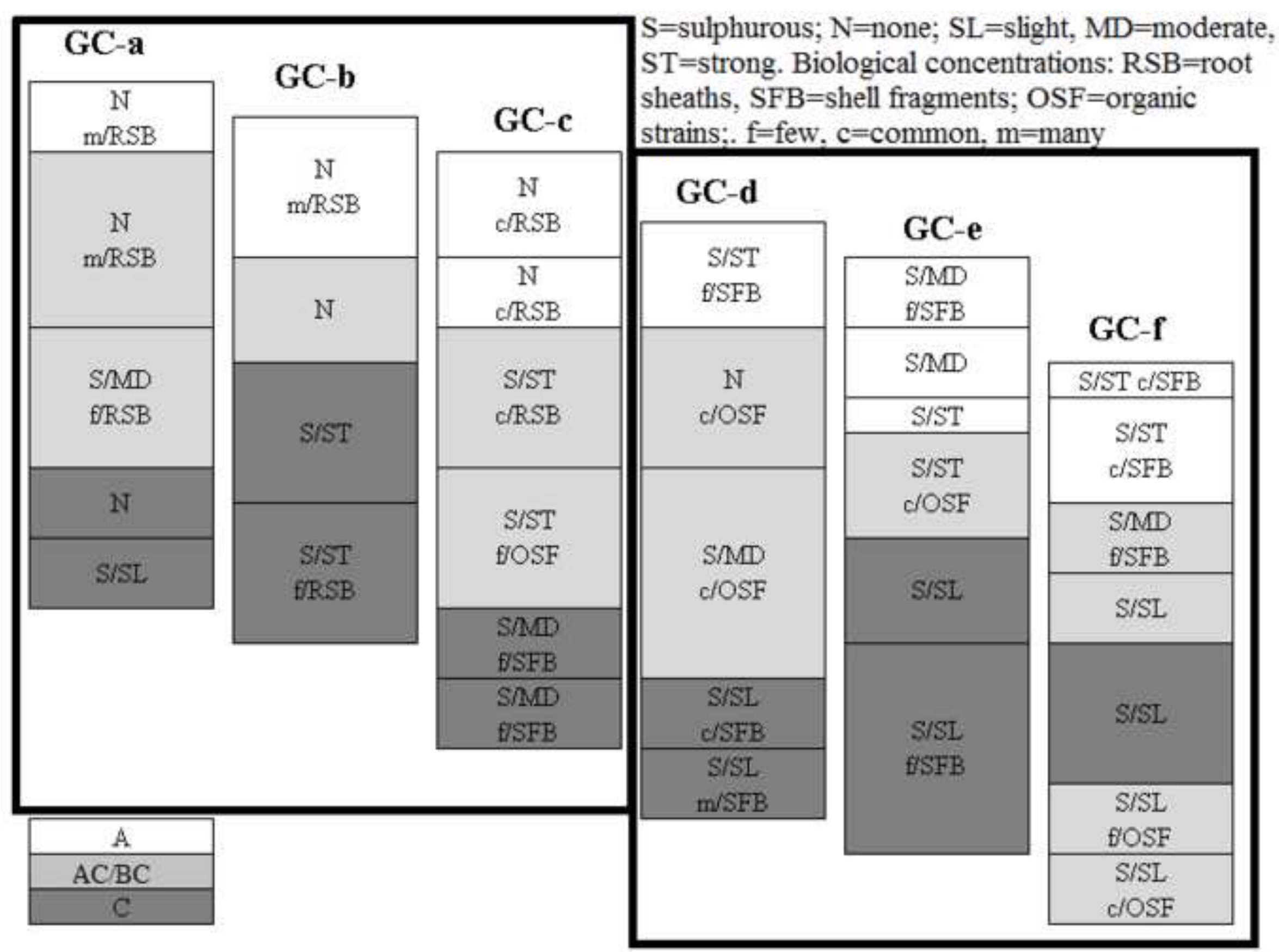




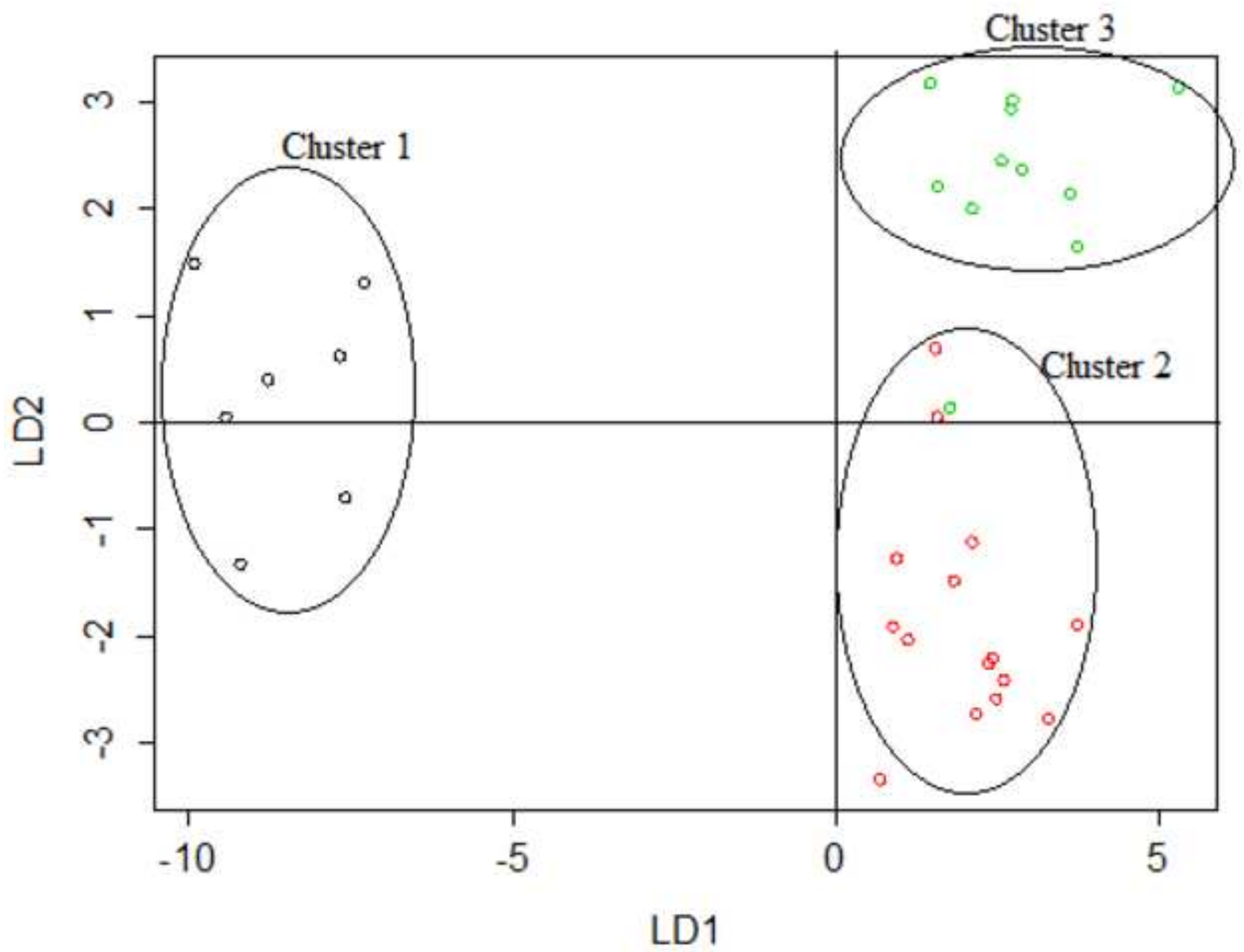



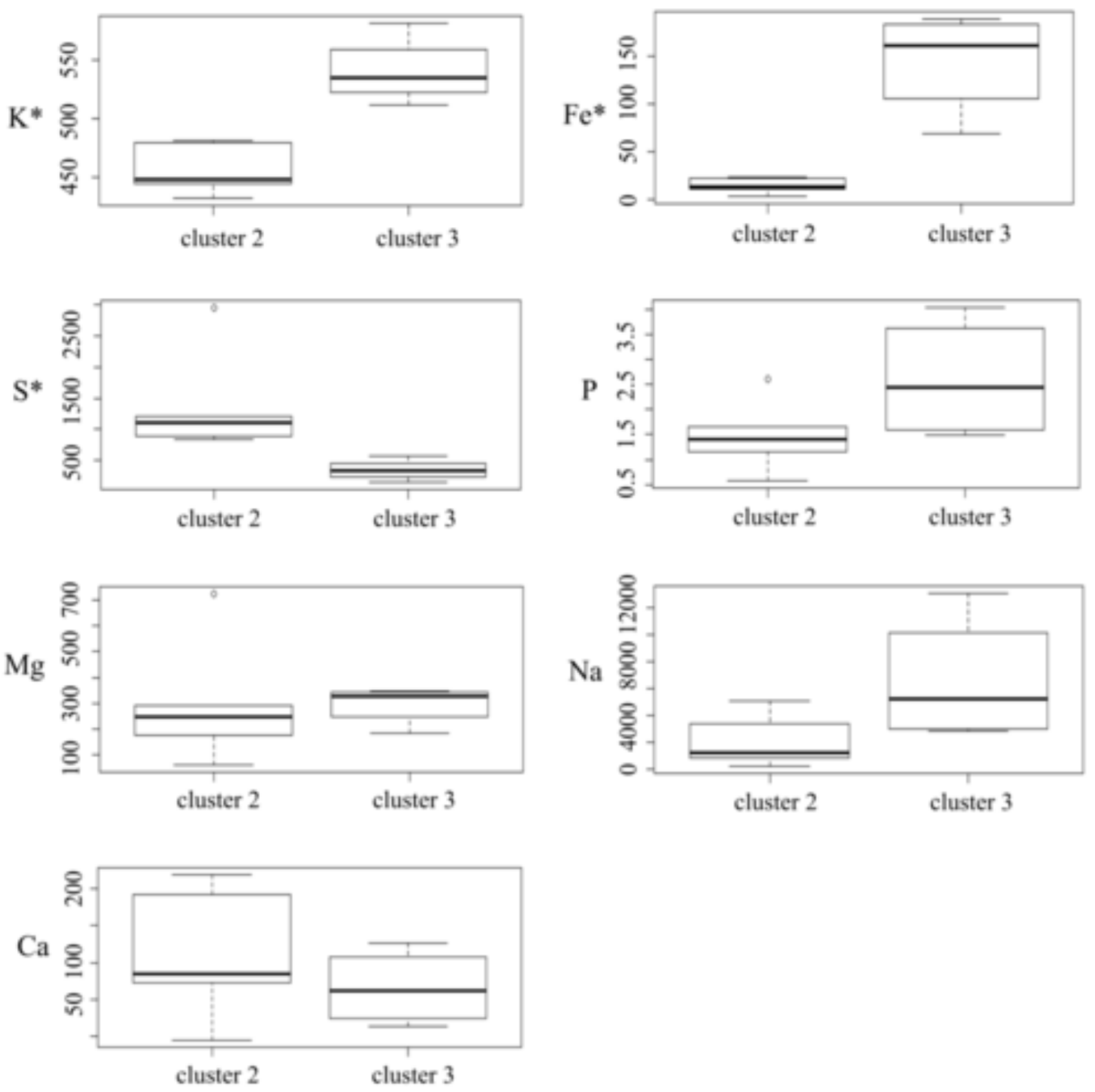
Table1S. Morphological features of investigated soils profiles. Codes according to Schoeneberger et al. (2012) and McVey et al (2012).

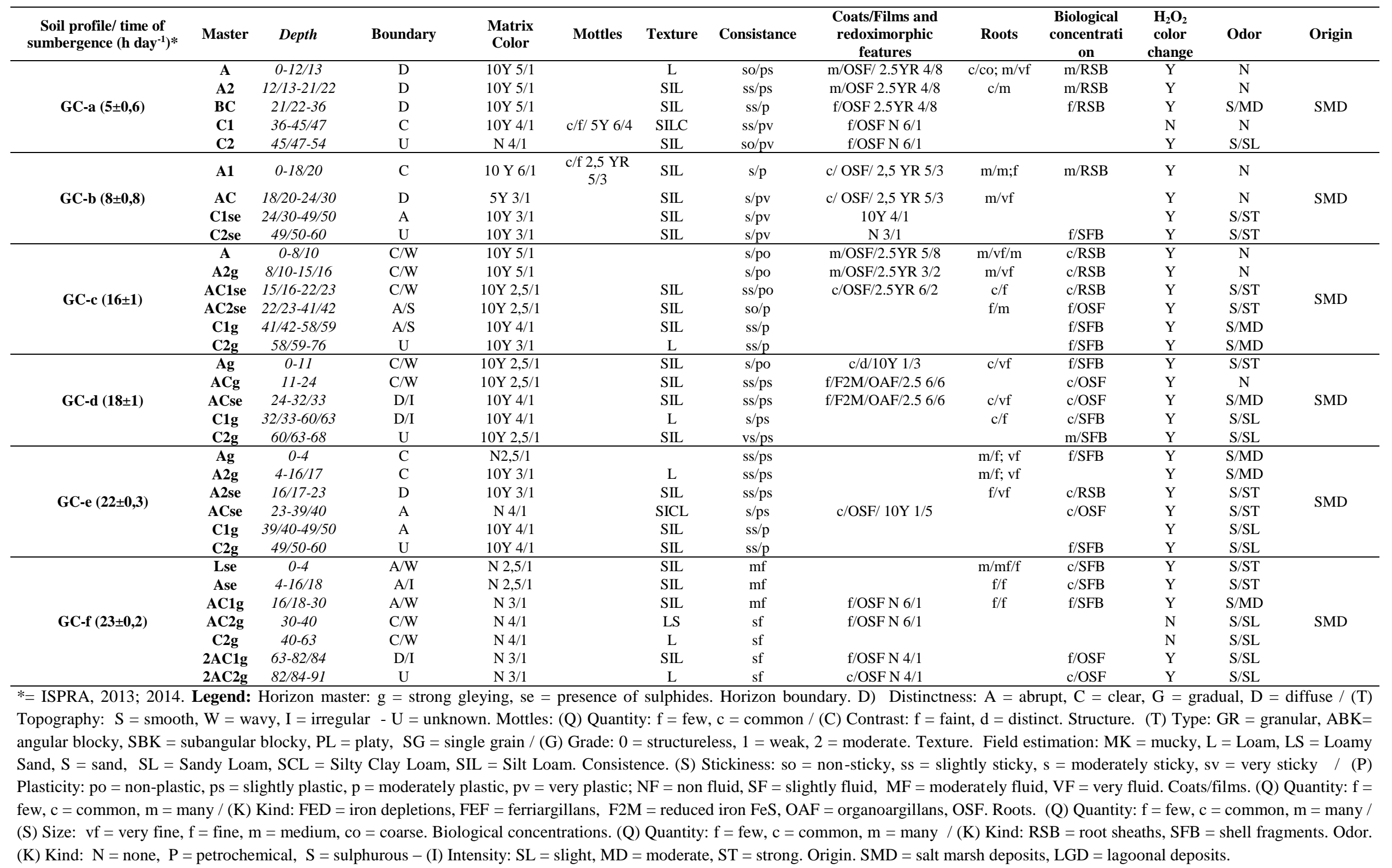

(K) Kind: $\mathrm{N}=$ none, $\mathrm{P}=$ petrochemical, $\mathrm{S}=$ sulphurous $-(\mathrm{I})$ Intensity: $\mathrm{SL}=$ slight, $\mathrm{MD}=$ moderate, $\mathrm{ST}=$ strong. Origin. $\mathrm{SMD}=$ salt marsh deposits, $\mathrm{LGD}=$ lagoonal deposits. 